\title{
NURSE CARE FOR DIABETIC FOOT PATIENT
}

\section{ORIGINAL ARTICLE}

CUNHA, Amanda Priscilla da ${ }^{1}$

CUNHA, Amanda Priscilla da. Nurse care for diabetic foot patient. Revista Científica Multidisciplinar Núcleo do Conhecimento. Year. 06, Ed. 12, Vol. 12, pp. 111-126. December 2021. ISSN: 2448-0959, Access link: https://www.nucleodoconhecimento.com.br/health/diabetic-foot, DOI: 10.32749/nucleodoconhecimento.com.br/health/diabetic-foot

\section{ABSTRACT}

Introduction: The diabetic foot also called by a multifaceted pathophysiological state is characterized by lesions that arise from the feet of the person with diabetes without adequate treatment and specific care. It is estimated that the incidence of diabetic foot ulcer reaches $6.3 \%$ of diabetic patients and its prevalence approaches $10 \%$, and people with low socioeconomic status are the greatest victims. In view of this evidence, the work is based on the following problem: What care do nurses develop in patients with diabetic feet? General objective: To evidence the care of diabetic foot related to the practice of nurses. Methodology: An integrative review was conducted in the Specialized Bibliographic Database in nursing (BDENF), latin american and caribbean literature in health sciences (LILACS) and the Scientific Electronic Library Online (SCIELO) and which resulted in seven articles. Results: The studies showed how the care of nurses with diabetic foot health education, continuing and permanent education, evaluation techniques to diabetic foot that involve physical examinations and self-care of patients with diabetic feet. It is reinforced that this care should be performed as a priority by nurses, since nurses have specific and qualified care to the patient in their main attributions. Conclusion: It is concluded, therefore, that the study identified several forms of care provided by nurses and that all these forms are

\footnotetext{
${ }^{1}$ Master in Hospital Management and Health Systems, Nurse Full Degree in Nursing. ORCID: 000-0001-54561848.
} 
important for the continuity of treatment and the prevention of complications, however, it is up to the nurse to be a professional who values the quality of their care based on theoretical concepts that lead to frequent training.

Keywords: Patient Care, Diabetes Mellitus, Diabetic foot.

\section{INTRODUCTION}

Diabetes Mellitus (DM) is a disease developed in the endocrine system and/or a chronic metabolic disorder, representing a serious worldwide health problem and has as its main characteristic hyperglycemia, reaching a blood glucose level greater than $126 \mathrm{mg} / \mathrm{dL}$ at fasting or $>200 \mathrm{mg} / \mathrm{dL}$ in the post prandial stage, and which may have been associated with insulin resistance, and which may have been associated with insulin resistance, inadequate insulin secretion or excessive glucagon secretion (ASCHNER et al., 2016).

Therefore, hyperglycemia causes total or partial incapacity of insulin production, according to the Brazilian Diabetes Society (SBD), American Diabetes Association (ADA) and World Health Organization (WHO) DM is divided into four groups: diabetes mellitus type 1, diabetes mellitus type 2, gestational diabetes mellitus and other specific types of diabetes (WHO, 1999; SBD, 2017; ADA 2017).

BdS describes risk factors for DM, which are cited as the following: diagnosis of prediabetes - decreased tolerance to glucose or altered fasting glucose; hypertension; hypercholesterolemia or changes in the rate of triglycerides in the blood; overweight and obesity, especially if fat is concentrated around the waist; family history; baby weighing more than four kilos or gestational diabetes; polycystic ovary syndrome; diagnosis of some psychiatric disorders, such as schizophrenia, depression, bipolar disorder and use of psychotropic medications; others (SBD, 2018).

Because it is a disease that affects approximately $3 \%$ of the world population and with an approximate prevalence of $6.2 \%$ of the population of Brazil, whose same is 
increased given the population aging (MUZY et al., 2021), DM has caused an inestraining in public coffers, besides also enabling high costs to treat its complications such as: diabetic foot, cardiovascular diseases, amputation and others. It is noteworthy that pharmacological treatment has been making progress for the control of DM, however, health education as a form of prevention should be transmitted to the general population individually or grouply emphasizing the problem of the disease and its health damage (SILVA, 2018).

Regarding the complications of DM, diabetic foot is also called by its multifaceted pathophysiological state, characterized by lesions that arise from the feet of the person with diabetes from neuropathy in $90 \%$ of cases, in which peripheral vascular disease and deformities are predominant (CUBAS et al., 2017).

De Sousa Mendonça; Moraes; Moura (2017) describes that the existing lesions in the diabetic foot come from the combination of two or more risk factors that may be related to intrinsic traumas such as extrinsic, associated with peripheral neuropathy causing loss of sensitivity, facilitating the risk of cuts; Peripheral vascular disease resulting from reduced blood flow in the lower limbs and biomechanical alteration that occurs when there is restriction of movements of the joints of the foot and ankle.

It is estimated that the incidence of diabetic foot ulcer reaches $6.3 \%$ of diabetic patients and its prevalence approaches $10 \%$, and people with low socioeconomic status are the greatest victims. The amputation of the diabetic foot is another problem and that worldwide every three minutes a person has his limb amputated due to DM (ARRUDA et al., 2021).

The good management of factors that are involved in the etiology of the existing lesion in the diabetic foot becomes effective when performed by the nurse, so the nurse must be qualified and qualified to perform the nursing consultation in order to unsee dermatological, musculoskeletal, vascular and neurological changes in the diabetic foot (FÉLIX et al., 2021). 
Therefore, the care of diabetic feet becomes very important within public health and the nurse, as a professional who has on his premise the care of the patient, should be attentive and qualified regarding the new forms of treatment to reduce amputations. In the face of this scenario of alarming rates, it is essential to observe how nurses are situated in practices in the care of diabetic feet.

Given this evidence that involves alarming numbers in relation to diabetic foot, the work is based on the following problem: What care do nurses develop in patients with diabetic feet?

The study in question aims to evidence the care of diabetic foot related to the practice of nurses.

\section{METHODOLOGY}

For this study, an integrative review of the literature was conducted. According to Mendes; Silveira and Galvão (2019), the integrative review method is developed following well-defined steps; they are: identification of the theme and selection of the northern question; establishing inclusion and exclusion criteria; identification of preselected and selected studies; categorization of selected studies; analysis and interpretation of the results and presentation of the summary of the review.

The first step of the integrative review is the northern issue, which leads to the theme and objectives listed. Therefore, the question that arises in this article is: What care do nurses develop in patients with diabetic feet?

To establish the inclusion criteria were used: articles published and available for reading, as the subject reflects the nurse in their attributions, the Database of BDENF, LILACS and SCIELO was chosen, the temporal delimitation was in the years 2016 to 2020, that is, in the last five years, and the Portuguese language was chosen for this inclusion. 
For the exclusion criteria were removed: articles that have duplicity, incomplete articles, annals, opinion texts, editorials and letters to the reader, review articles, theses, dissertations, full texts, but that do not relate to the theme.

The period of data collection corresponded to the month of September 2021. The national descriptors identified were: "nursing care", "diabetic foot", "Nurse", "diabetes mellitus". The boolean operator and was used to associate the descriptors in the search strategy on the database platform.

For the selection of selected and pre-selected studies, a thorough reading of the titles and abstracts of the articles found was made, and then a more complete reading throughout the article, looking in its results for the identification to achieve the objective proposed in this article.

Two searches were carried out, the first used the following search strategy: nursing care and diabetic foot and diabetes mellitus, with this strategy, 186 articles were found. After using the filters: full and available text, database, Portuguese language and temporal delimitation of the last five years, 24 articles remained for eligibility. The second search was performed with the following strategy: nurse and diabetic foot finding 95 articles. After using the filters, 11 articles remained for eligibility.

The studies were categorized from a sinoptic picture and the analysis and presentation of the results was conducted after the categorization which identified and defined the meaning nuclei of the studies, and from the thematic analysis of Minayo (2012), there was discussion among the authors.

For the synthesis of knowledge, an analysis of the limitations, representativeness of the study for the community in general (relevance) and future studies identified in the course of this article was made. All the productions used in this study are rigorously referenced according to the standards of the Brazilian Association of Technical Standards (ABNT). 


\section{RESULTS AND DISCUSSIONS}

The remaining articles for eligibility with both strategies totaled 35 articles. Initially, review articles, course completion papers, letters to the reader, experience reports, case studies, duplicate articles were removed and that in their titles, abstracts and reading in full did not bring the nurse and his care as a theme to the subject, thus leaving 07 articles for this review.

For a better illustration of the results found, the following table will include the characterization of the selected studies. The data refer to: article title, year of publication, database, journal, location, objective and results.

Table one. Articles found in the BDENF, LILACS and SCIELO database on nursing care for patients with diabetic feet.

\begin{tabular}{|c|c|c|c|c|c|}
\hline $\begin{array}{l}\text { Title/ Year of } \\
\text { publication }\end{array}$ & $\begin{array}{l}\text { Databas } \\
\text { e }\end{array}$ & periodic & Goal & Local & Findings \\
\hline $\begin{array}{l}\text { Conhecimento } \\
\text { do enfermeiro } \\
\text { acerca dos } \\
\text { cuidados com } \\
\text { o pé diabético } \\
2019\end{array}$ & BDENF & $\begin{array}{l}\text { Rev. } \\
\text { enferm. } \\
\text { UFPE } \\
\text { on line }\end{array}$ & $\begin{array}{l}\text { Understandin } \\
\mathrm{g} \text { the nurse's } \\
\text { knowledge } \\
\text { about diabetic } \\
\text { foot care in } \\
\text { Primary Care }\end{array}$ & $\begin{array}{l}\text { Family } \\
\text { Health } \\
\text { Strategy/ES } \\
\text { F }\end{array}$ & $\begin{array}{l}\text { Periodically } \\
\text { perform } \\
\text { physical } \\
\text { examination } \\
\text { of the feet in } \\
\text { diabetics; } \\
\text { Use } \\
\text { instruments } \\
\text { for evaluation } \\
\text { of diabetic } \\
\text { foot } \\
\text { Self-care at } \\
\text { the feet }\end{array}$ \\
\hline $\begin{array}{l}\text { Riscos } \\
\text { associados à }\end{array}$ & $\begin{array}{l}\text { LILACS/ } \\
\text { BDENF }\end{array}$ & $\begin{array}{l}\text { Rev. } \\
\text { gaúch. }\end{array}$ & $\begin{array}{l}\text { Identify in } \\
\text { patients with }\end{array}$ & $\begin{array}{l}\text { Educational } \\
\text { program for }\end{array}$ & $\begin{array}{l}\text { Health } \\
\text { education on }\end{array}$ \\
\hline
\end{tabular}




\begin{tabular}{|c|c|c|c|c|c|}
\hline $\begin{array}{l}\text { mortalidade } \\
\text { em pacientes } \\
\text { atendidos em } \\
\text { um programa } \\
\text { de prevenção } \\
\text { do pé } \\
\text { diabético } \\
2018\end{array}$ & & enferm & $\begin{array}{l}\text { type } \\
\text { diabetes what } \\
\text { changes in } \\
\text { the feet would } \\
\text { be associated } \\
\text { with } \\
\text { demographic, } \\
\text { clinical, } \\
\text { biochemical } \\
\text { and treatment } \\
\text { characteristic } \\
\text { s and which } \\
\text { of them would } \\
\text { increase the } \\
\text { risk } \\
\text { mortality }\end{array}$ & $\begin{array}{l}\text { prevention } \\
\text { and } \\
\text { treatment of } \\
\text { diabetic foot } \\
\text { in a general } \\
\text { and } \\
\text { university } \\
\text { hospital of } \\
\text { high } \\
\text { complexity }\end{array}$ & $\begin{array}{l}\text { foot hygiene, } \\
\text { the choice of } \\
\text { appropriate } \\
\text { footwear, the } \\
\text { best conduct } \\
\text { in emergency } \\
\text { situations. } \\
\text { Systemic care } \\
\text { such as not } \\
\text { smoking, } \\
\text { maintaining } \\
\text { good glycemic } \\
\text { control, } \\
\text { controlling } \\
\text { blood lipid } \\
\text { rates and the } \\
\text { correct use of } \\
\text { medications }\end{array}$ \\
\hline $\begin{array}{l}\text { Condutas dos } \\
\text { enfermeiros } \\
\text { da atenção } \\
\text { primária no } \\
\text { cuidado a } \\
\text { pessoas com } \\
\text { pé diabético } \\
2017\end{array}$ & BDENF & $\begin{array}{l}\text { Rev. } \\
\text { enferm. } \\
\text { UFPE } \\
\text { on line }\end{array}$ & $\begin{array}{l}\text { To know the } \\
\text { actions of } \\
\text { primary care } \\
\text { nurses in the } \\
\text { care of } \\
\text { people with } \\
\text { Diabetes } \\
\text { Mellitus (DM) } \\
\text { related to } \\
\text { diabetic foot }\end{array}$ & $\begin{array}{l}\text { Family } \\
\text { Health } \\
\text { Strategy }\end{array}$ & $\begin{array}{l}\text { Frequency } \\
\text { and } \\
\text { scheduling of } \\
\text { consultations, } \\
\text { service } \\
\text { dynamics, } \\
\text { criteria for foot } \\
\text { examination, } \\
\text { self-care }\end{array}$ \\
\hline $\begin{array}{ll}\text { Ações do } & \text { do } \\
\text { enfermeiro na } \\
\text { prevenção do }\end{array}$ & $\begin{array}{l}\text { LILACS/ } \\
\text { BDENF }\end{array}$ & $\begin{array}{l}\text { Rev. } \\
\text { Pesqui. } \\
\text { (Univ. }\end{array}$ & $\begin{array}{l}\text { Investigate } \\
\text { the actions } \\
\text { carried out by }\end{array}$ & $\begin{array}{l}\text { University } \\
\text { extension } \\
\text { project }\end{array}$ & $\begin{array}{l}\text { Specific } \\
\text { actions, which } \\
\text { properly }\end{array}$ \\
\hline
\end{tabular}


REVISTA CIENTIFICA MULTIDISCIPLINAR NÚCLEO DO CONHECIMENTO ISSN: 2448-0959

\begin{tabular}{|c|c|c|c|c|c|}
\hline $\begin{array}{l}\text { pé diabético: } 0 \\
\text { olhar da } \\
\text { pessoa com } \\
\text { diabetes } \\
\text { mellitus } \\
2017\end{array}$ & & $\begin{array}{l}\text { Fed. } \\
\text { Estado } \\
\text { Rio J., } \\
\text { Online) }\end{array}$ & $\begin{array}{l}\text { nurses in the } \\
\text { prevention of } \\
\text { diabetic foot } \\
\text { from the } \\
\text { perspective of } \\
\text { the person } \\
\text { with DM. }\end{array}$ & & $\begin{array}{l}\text { involve foot } \\
\text { examination, } \\
\text { communicativ } \\
\text { e dialogue, } \\
\text { health } \\
\text { education. }\end{array}$ \\
\hline $\begin{array}{l}\text { Alterações } \\
\text { nos pés do } \\
\text { idoso } \\
\text { hospitalizado: } \\
\text { um olhar } \\
\text { cuidadoso da } \\
\text { enfermagem } \\
2017\end{array}$ & $\begin{array}{l}\text { LILACS/ } \\
\text { BDENF }\end{array}$ & $\begin{array}{l}\text { Esc. } \\
\text { Anna } \\
\text { Nery } \\
\text { Rev. } \\
\text { Enferm }\end{array}$ & $\begin{array}{l}\text { To } \\
\text { characterize } \\
\text { the } \\
\text { podological } \\
\text { profile of } \\
\text { elderly } \\
\text { hospitalized } \\
\text { in the wards } \\
\text { of a university } \\
\text { hospital; } \\
\text { identify the } \\
\text { foot care } \\
\text { demands of } \\
\text { hospitalized } \\
\text { elderly } \\
\text { patients; and } \\
\text { to analyze the } \\
\text { possibilities of } \\
\text { nurses' } \\
\text { actions with } \\
\text { these elderly. }\end{array}$ & Hospital & $\begin{array}{l}\text { Strengthening } \\
\text { the bonds with } \\
\text { these diabetic } \\
\text { patients so } \\
\text { that they } \\
\text { come to the } \\
\text { post to } \\
\text { frequently } \\
\text { perform foot } \\
\text { exams } \\
\text { Training and } \\
\text { qualification to } \\
\text { assist these } \\
\text { problems, } \\
\text { avoiding } \\
\text { greater } \\
\text { complications } \\
\text { and reducing } \\
\text { future care } \\
\text { demands }\end{array}$ \\
\hline $\begin{array}{l}\text { Atuação dos } \\
\text { enfermeiros } \\
\text { da estratégia }\end{array}$ & $\begin{array}{l}\text { LILACS/ } \\
\text { BDENF }\end{array}$ & $\begin{array}{l}\text { Rev. } \\
\text { Pesqui. } \\
\text { (Univ. }\end{array}$ & $\begin{array}{l}\text { Identify } \\
\text { guidance } \\
\text { provided by }\end{array}$ & $\begin{array}{l}\text { Family } \\
\text { Health } \\
\text { Strategy }\end{array}$ & $\begin{array}{l}\text { Health } \\
\text { education for } \\
\text { diabetics, }\end{array}$ \\
\hline
\end{tabular}




\begin{tabular}{|c|c|c|c|c|c|}
\hline $\begin{array}{l}\text { saúde da } \\
\text { família na } \\
\text { prevenção do } \\
\text { pé diabético } \\
2016\end{array}$ & & $\begin{array}{l}\text { Fed. } \\
\text { Estado } \\
\text { Rio J., } \\
\text { Online) } \\
\text {; }\end{array}$ & $\begin{array}{l}\text { nurses to } \\
\text { people with } \\
\text { DM on foot } \\
\text { care; To } \\
\text { investigate } \\
\text { the frequency } \\
\text { of foot } \\
\text { examination } \\
\text { and } \\
\text { aspects } \\
\text { evaluated; to } \\
\text { verify which } \\
\text { health } \\
\text { education } \\
\text { activities } \\
\text { nurses } \\
\text { perform for } \\
\text { people with } \\
\text { DM. }\end{array}$ & & $\begin{array}{l}\text { examination } \\
\text { of the feet of } \\
\text { people with } \\
\text { DM, formation } \\
\text { of coexistence } \\
\text { groups, } \\
\text { dressings in } \\
\text { techniques } \\
\text { appropriate to } \\
\text { the type of } \\
\text { foot injury. }\end{array}$ \\
\hline $\begin{array}{l}\text { A perspectiva } \\
\text { da } \\
\text { vulnerabilidad } \\
\text { e na avaliação } \\
\text { do pé } \\
\text { diabético sob } \\
\text { a ótica de } \\
\text { enfermeiros } \\
2016\end{array}$ & BDENF & $\begin{array}{l}\text { Cogitar } \\
\text { e } \\
\text { enferm }\end{array}$ & $\begin{array}{l}\text { Write the } \\
\text { social } \\
\text { determinant } \\
\text { conditions in } \\
\text { health, } \\
\text { identified by } \\
\text { nurses as } \\
\text { relevant for } \\
\text { the } \\
\text { establishment } \\
\text { of } \\
\text { vulnerabilities }\end{array}$ & $\begin{array}{l}\text { Randomly } \\
\text { chosen } \\
\text { nurses in } \\
\text { Curitiba }\end{array}$ & $\begin{array}{l}\text { Stimulate the } \\
\text { diabetic to go } \\
\text { for nutritional } \\
\text { assessment } \\
\text { and follow a } \\
\text { diet. }\end{array}$ \\
\hline
\end{tabular}




\section{of the person \\ with Diabetes \\ Mellitus.}

Source: Author.

The study in its objectives mention three types of care performed by nurses for patients with diabetic feet: The first one that most emerged is based on actions aimed at health education as a fundamental principle of disease prevention and its complications, the second care is based on foot assessment techniques in diabetics as a way of arising from complications and the third care focuses on nurses as a stimulator and motivator diabetic patients to their self-care with their feet. These three precautions will be discussed in their themes according to the selected studies.

\subsection{HEALTH EDUCATION AS A FORM OF PREVENTION}

Therefore, from health education, the patient can understand the reasons why the wound healing process is slow, the reasons for the main complications and especially the knowledge related to risk prevention. Nurses should be able to recognize the needs of the patient and thus contribute to accurate and safe nursing diagnoses related to the wound in its stage.

Scain; Franzen; Hirakata (2018) report that nurses have been maintaining efforts to perform health education with patients, becoming persistent and insistent to continue the educational process in patients with diabetic feet, use creativity with the development of educational technologies such as folders, videos, as well as being available to ask questions about some abnormal condition with the patient from social media technologies such as Whatsapp/phone.

Camillo et al. (2016) mentions that the concept of health education goes beyond bringing data or even removing doubts that arise, the authors consider health education a systematic, continuous and permanent process, aiming at the formation and development of critical awareness of the citizen, through the search for collective 
solutions to the problems experienced and their "real participation" in the exercise of social control.

Vargas et al. (2017) brings health education as one of the main purposes of nurses' attributions to care, the authors reinforce that health education favors the patient a more proactive posture, demonstrating that the patient should have security about the care of the diabetic foot.

Autonomy and safety of care were also pointed out as results of health education performed by nurses in the study by Pereira et al. (2017), the authors report that health education becomes the main mechanism of prevention against diseases and their complications, in relation to diabetic foot, health education promotes patient safety, trust and autonomy.

The demonstration that health education is effective was identified in a descriptive study of quantitative approach in which it showed that health education brought patients a theoretical knowledge about the disease respecting the culture and belief of patients, and that the promotion of educational processes takes place not only together, but in an individualized way, taking away the doubts that permeate the patient during the nursing consultation or even in an informal dialogue between the patient and the professional (DE OLIVEIRA et al., 2016).

But health education is not only identified as a process of care for patients, nurses should also be attentive to training and qualifications, which can also be considered a health education in a more technical way. Silva; Santo and Chibante (2017) states that nurses should always be updated to new ways of caring for diabetic feet, since treatment processes are increasingly being studied in the scientific literature and bring innovations for healing or even wound staging.

Therefore, health education, continuing education and continuing education are forms of care that nurses use to improve the clinical picture of patients with diabetic feet. 


\subsection{DIABETIC FOOT EVALUATION TECHNIQUES}

The technical-scientific knowledge acquired during the phases of nursing education and in the context of continuing and permanent education are relevant factors for the treatment of diabetic foot, therefore, it is up to the nurse to seek knowledge to perform safe evaluation techniques for patients with diabetes as a method of prevention and to patients with diabetic foot as prevention measures for complications.

Arruda et al. (2019) states that the physical examination of diabetic feet are procedures performed by nurses in order to avoid possible complications such as: development of ulcers and amputations of the lower limbs. Therefore, the ignorance of this technique induces the higher rates of complications. The authors point out at another time that in addition to the technique not being used due to lack of knowledge of the nurse, the working conditions also influence the non-performance of the evaluation technique, these conditions are referred to by the authors as inadequate infrastructure and demand for excessive care.

Vargas et al. (2017) brings in its study a similar context to the previously mentioned study and adds that nurses need more training regarding evaluation techniques related to diabetic foot, nurses also report that management does not offer materials to perform these techniques and talk about excessive demands.

Pereira et al. (2017) considers that specific actions should be taken to reshape the care system for patients with diabetic foot, these actions should be related beyond the foot examination, presenting effective communication and health education.

Leal et al. (2016) considers that nurses may have ignorance of the subject due to several factors and one of them is pointed out by the authors as the high demand for care. This demand implies physical and mental exhaustion of the professional, which provides a lack of time for professional qualification. In another sense, the authors mention that the excessive demand for a given problem provides the professional to make room for permanent health education, in which this type of training proposes 
transformations in professional practices based on existing problems in the process of their work learning to reflect the practice within their reality.

Nursing carries with it the function of treating diseases of the skin and its adjacent diseases. This is because nurses have in their attributions the care of the patient and the need to expand this care associated with skin-related diseases (DA SILVA BRANDAO et al., 2016; SA et al., 2016).

\subsection{THE NURSE MEDIATOR FOR SELF-CARE TO DIABETIC FOOT PATIENTS}

Speaking of self-care refers to any and all action derived from the daily act of the human being. As for the self-care Arruda et al. (2019) report that patients with diabetic foot tend to generate a great economic, social, cultural, emotional and biological impact, which favors a greater dependence on others to help in daily life activities and an impact on their self-care and quality of life.

Scain; Franzen and Hirakata (2018) report that the patient should be aware of the performance of his own activities and that self-care should be continuous, one of the ways to perform self-care cited by the authors were: Hygiene of the feet; choice of appropriate footwear; avoid walking barefoot and others.

Vargas et al. (2017) brings as self-care the maintenance of glycemic control, the proactive participation of patients in the performance of foot examinations, therapy, absolute restriction to the use of tobacco and beverages, nutrition, physical exercise, physical activity and other forms that contemplate the study previously referenced.

A way to achieve that the patient can aim for self-care is cited by the authors Silva; Santo and Chibante (2017) as the strengthening of bonds between the patient and health professional. This strengthening favors the safety and credibility of the patient performing self-care to the feet in a continuous and systematic way, the lower the chances of risk of complications. 
The autonomy and safety demonstrated by patients with diabetic foot minimize damage and risks of complications. A patient who is involved in the treatment of his disease tends to expand his knowledge to the non-dependence of other people, articulating in his activities self-care as a form of motivation and demonstration of capacity in the face of adversities that involve the health-disease process (DE OLIVEIRA et al., 2016).

To Fátima Bento et al. (2016), patients with diabetic feet already suffer stigmas from their condition, which makes it difficult for them to have adequate care, because the conditions that involve distancing themselves from the health unit, difficulties in mobilizing, little knowledge about the disease, allow inadequate care and evolution of complications.

However, Nascimento et al. (2016) mention that when qualified and humanized care is provided through effective conducts, with easy access to health services to which all actions can be integrated at all levels of care, self-care without risk of complications.

\section{CONCLUSION}

This study reflected on the care of nurses and professionals in the performance of care and care for patients with diabetic foot. The relevant care studies identified what led to the realization of three themes for the discussion of the results found.

The aim of the study was to highlight the care provided to nurses to patients with diabetic feet, it is emphasized that care of nurses and not other categories of nursing was emphasized. The studies demonstrated health education as the first care, which cannot be contradicted, since the literature emphasizes that health education is paramount for disease prevention.

Another type of care is reflected in the professional's own knowledge about the diabetic foot, of extreme need and great concern within the health system, since the 
articles brought reflections that nurses should be more qualified to direct care with more excellence to the patient.

An important care also pointed out by the studies and that is directed directly with the permanent or continuing education of professionals are the techniques of physical examination, in this type of care, the nurse should be able to perform the examination of diabetic feet wisely and safely, besides also encouraging patients to go to the examination more frequently.

Regarding the care related to the patient's own self-care, it was reflected that foot hygiene, glycemic control, continuous follow-up with foot examination, the use of appropriate shoes and others intensify a greater prevention against complications among them the amputation of limbs.

It is concluded, therefore, that the study identified several forms of care provided by nurses and that all these forms are important for the continuity of treatment and prevention and complications, however, it is up to the nurse to be a professional who values the quality of their care based on theoretical concepts that lead to frequent training.

\section{REFERENCES}

AMERICAN DIABETES ASSOCIATION. Standards of medical care in diabetes. Diabetes Care, v. 40, n. suppl 1, p. s1-s128, 2017.

ARRUDA, Cecilia et al. Tecnologia educativa para cuidados e prevenção do pé diabético/Educational technology for care and prevention of diabetic foot ulcers. Ciência, Cuidado e Saúde, v. 20, 2021.

ARRUDA, Luana Savana Nascimento de Sousa et al. Conhecimento do enfermeiro acerca dos cuidados com o pé diabético. Rev. enferm. UFPE on line, p. [1-8], 2019. 
ASCHNER M, Pablo et al. Clinical practice guideline for the prevention, early detection, diagnosis, management and follow up of type 2 diabetes mellitus in adults. Colomb. Med., Cali, v. 47, n. 2, p. 109-130, junho. 2016.

CAMILLO, Bibiana Schultz et al. Ações de educação em saúde na atenção primária a gestantes e puérperas: revisão integrativa. Revista de enfermagem UFPE on line-ISSN: 1981-8963, v. 10, n. 6, p. 4894-4901, 2016.

CUBAS, Marcia Regina et al. Pé diabético: orientações e conhecimento sobre cuidados preventivos. Fisioterapia em movimento, v. 26, n. 3, 2017.

DE FÁTIMA BENTO, Leandra et al. A perspectiva da vulnerabilidade na avaliação do pé diabético sob a ótica de enfermeiros. Cogitare Enfermagem, v. 21, n. 1, 2016.

DE OLIVEIRA, Patrícia Simplício et al. Atuação dos enfermeiros da Estratégia Saúde da Família na prevenção do pé diabético Practice nurse family health strategy in the prevention of diabetic foot. Revista de Pesquisa Cuidado é Fundamental Online, v. 8, n. 3, p. 4841-4849, 2016.

DE SOUZA MENDONÇA, Sarah; MORAIS, Juliana de Sant'Anna; DE MOURA, Maria Catarina Gomes Gadelha. Proposta de um protocolo de avaliação fisioterapêutica para os pés de diabéticos. Fisioterapia em Movimento, v. 24, n. 2, 2017.

FELIX, Lidiany Galdino et al. Conhecimento de enfermeiros da atenção primária antes e após intervenção educativa sobre pé diabético. Revista Gaúcha de Enfermagem, v. 42, 2021.

LEAL, Maria do Carmo et al. Atenção ao pré-natal e parto em mulheres usuárias do sistema público de saúde residentes na Amazônia Legal e no Nordeste, Brasil 2010. Rev. Bras. Saude Mater. Infant. Recife, v. 15, n. 1, p. 91-104, Mar. Available from \&lt; http://www.scielo.br/scielo.php?script=sci_arttext\&amp;pid=S1519$38292015000100091 \& a m p ;$ Ing=en\&amp;nrm=iso\&gt;. 
MENDES, Karina Dal Sasso; SILVEIRA, Renata Cristina de Campos Pereira; GALVÃO, Cristina Maria. Uso de gerenciador de referências bibliográficas na seleção dos estudos primários em revisão integrativa. Texto \& ContextoEnfermagem, v. 28, 2019.

MINAYO, Maria Cecília de Souza. Análise qualitativa: teoria, passos e fidedignidade. Ciência \& saúde coletiva, v. 17, p. 621-626, 2012.

MUZY, Jéssica et al. Prevalência de diabetes mellitus e suas complicações e caracterização das lacunas na atenção à saúde a partir da triangulação de pesquisas. Cadernos de Saúde Pública, v. 37, 2021.

NASCIMENTO, Vagner Ferreira do et al. Percepção de puérperas sobre as primeiras consultas de pré-natal no interior de Mato Grosso. Rev. enferm. UFPI, v.5, n. 1, p. 46-51, 2016.

ORGANIZAÇÃO MUNDIAL DE SAÚDE. Definition, diagnosis and classification of diabetes Mellitus and its complications. Geneva: OMS, 1999. Disponível em: https://apps.who.int/iris/bitstream/handle/10665/66040/WHO_NCD_NCS_99.2.pdf?s equence $=1$ \&isAllowed $=\mathrm{y}$

PEREIRA, Laiane de Fátima et al. Ações do enfermeiro na prevenção do pé diabético: o olhar da pessoa com diabetes mellitus. Rev. pesqui. cuid. fundam. (Online), p. 1008-1014, 2017.

SCAIN, Suzana Fiore; FRANZEN, Elenara; HIRAKATA, Vânia Naomi. Riscos associados à mortalidade em pacientes atendidos em um programa de prevenção do pé diabético. Revista Gaúcha de Enfermagem, v. 39, 2018.

SILVA, Caline Oliveira da. Análise da qualidade de vida em indivíduos com Diabetes Mellitus Tipo 1. 2017. $34 \mathrm{f}$. Trabalho de conclusão de curso (Bacharelado em Farmácia) -Universidade de Brasília, Brasília, 2017. Disponível em: https://bdm.unb.br/handle/10483/19301 
SILVA, Joziane Santos da; SANTO, Fátima Helena do Espírito; CHIBANTE, Carla Lube de Pinho. Alterações nos pés do idoso hospitalizado: um olhar cuidadoso da enfermagem. Escola Anna Nery, v. 21, 2017.

SOCIEDADE BRASILEIRA DE DIABETES. Tratamento e acompanhamento do diabetes Mellitus: Diretrizes da Sociedade Brasileira de Diabetes. 3.ed. Itapevi, SP: A. Araújo Silva Farmacêutica; 2017/2018. Disponível em: http://www.diabetes.org.br/ profissionais/images/2017/diretrizes/diretrizes-sbd-20172018.pdf.

VARGAS, Caroline Porcelis et al. Condutas dos enfermeiros da atenção primária no cuidado a pessoas com pé diabético. Rev. enferm. UFPE on line, p. 4535-4545, 2017.

Submitted: October, 2021.

Approved: December, 2021. 